\title{
IN VITRO SENSIVITY OF FIG PLANTLETS TO GAMMA RAYS
}

\author{
Ester Alice Ferreira ${ }^{1 *}$; Moacir Pasqual²; Augusto Tulmann Neto ${ }^{3}$ \\ ${ }^{1}$ EPAMIG/CTTP, C.P. 351 - 38001-970 - Uberaba, MG - Brasil. \\ ${ }^{2}$ UFLA - Depto. de Agricultura, C.P. 37 - 37200-000 - Lavras, MG - Brasil. \\ ${ }^{3}$ USP/CENA - Lab. de Melhoramento de Plantas, C.P. 96 - 13400-970 - Piracicaba, SP - Brasil. \\ *Corresponding author <ester@epamig.br>
}

\begin{abstract}
Fig breeding programs through conventional methods are rare in many countries, e.g. Brazil, since the wasp Blastophaga psenes, which is responsible for the natural pollination, is not present. For these cases a low cost alternative for the breeding program is the induction of physical mutagenesis by radiation. The sensivity of fig explant buds of different sizes to gamma radiation were evaluated. Fig plantlets "Roxo de Valinhos" already established in vitro were classified by size in 2.5 to $4.5 \mathrm{~cm}, 5$ to $97 \mathrm{~cm}$ and 8 to $10 \mathrm{~cm}$ long, and irradiated with: 10, 20, 30, 40 and 50 Gy doses. After irradiation each plantlet was cut in pieces containing one-bud and transferred to WPM culture medium, according to the bud position: medium and apical. Explants were grown in a growth room for 90 days when, explant mortality, root formation, height of aerial part, number of buds and plantlet weight were evaluated. Doses of up to 50 Gy do not cause plantlet death and that doses larger than 30 Gy inhibit root formation. Therefore, the 30 Gy dose may be recommended for the irradiation of fig plantlets larger than $2.5 \mathrm{~cm}$.
\end{abstract}

Key words: mutation, breeding, tissue culture

\section{SENSITIVIDADE IN VITRO DE BROTAÇÕES DE FIGUEIRA À RADIAÇÃO GAMA}

\begin{abstract}
RESUMO: Os programas de melhoramento de figueira por métodos convencionais são raros em muitos países, como o Brasil, por exemplo, por não ser encontrada a mosca Blastophaga psenes responsável pela polinização natural. Para estes casos, uma alternativa de baixo custo para os programas de melhoramento é a irradiação, por meio de mutagênicos físicos. Avaliou-se o efeito de doses de radiação gama em gemas de explantes de figueira de diferentes tamanhos. Foram usadas plântulas previamente estabelecidas in vitro, que foram separadas nos tamanhos: 2,5 a 4,5 cm; 5 a $7 \mathrm{~cm}$ e 8 a 10 cm e irradiadas nas doses 10, 20, 30, 40 e 50 Gy. Após a irradiação, as plântulas foram repicadas em explantes contendo uma gema e, na inoculação no meio nutritivo WPM, foram separadas em função da posição de gemas: basal, mediana e apical. Após 90 dias em sala de crescimento, foram avaliadas as seguintes características: mortalidade de explantes, formação de raízes, comprimento da parte aérea, número de gemas e peso das plântulas. Doses de até 50 Gy não provocam morte de plântulas e que doses acima de 30 Gy impedem a formação de raízes sendo esta recomendada como a dose para irradiação de plântulas de figueira maiores que $2,5 \mathrm{~cm}$.

Palavras-chave: mutação, melhoramento, cultura de tecidos
\end{abstract}

\section{INTRODUCTION}

In Brazilian orchards, Ficus carica L cultivar 'Roxo de Valinhos' has prevailed due to its great vigor, rusticity, productivity and acceptance by both consumers and producers. However, this cultivar holds some undesirable characteristics that may put at risk the present production and also endanger the expansion to new areas. The susceptibility to the mosaic virus and to the gall and cyst nematodes are the main problems of this culture and can only be minimized or solved with the use of resistant cultivars. Breeding programs, that use conventional methods to obtain new cultivars, is not in progress in Brazil. The main barriers or restrictions found by breeding professionals are the small genetic variability and the difficulty to obtain plants originated by gamete fusion, since Blastophaga psenes, the wasp responsible for the natural pollination, does not exist in the country. 
In such cases, a low cost alternative for the breeding program is the induction of mutagenesis by radiation (different types of radiation) which has been used in plant breeding, which increases the genetic variability and allows desirable genotypes to be obtained (Tulmann Neto et al., 1999). Reports have shown the use of this technique for the genetic improvement of fig trees (Spiegel-Roy, 1990), even in Brazil, where Santos et al. (1997) started a project aiming mutation induction by the use of 'Roxo de Valinhos' dormant cuttings, which is still under evaluation. The irradiation of in vitro explants presents some advantages, such as the ease of handling the material, the fast obtainment of subsequent generations and, in some cases, in vitro evaluation. This technique has already been used successfully in ornamental plants (Nagatomi 2003) and several fruit plants, such as: banana (Domingues et al., 1994), citrus (Cristofani et al., 1993), Japanese plum (Prunus saliciana Lindl.) cv. Shiro (Predieri \& Gatti, 2000) and rootstock of 'Gravesac' grape (Silva \& Doazan, 1998).

This study evaluated the effect of gamma radiation doses in the performance of fig tree plantlets of different sizes, considering the bud position, and having as goal the use of mutation for breeding fig trees.

\section{MATERIALAND METHODS}

Plantlets of fig tree, cv. 'Roxo de Valinhos', established in vitro and with well-formed aerial part and root system, were used. These plantlets were cultivated in test tubes containing Wood Medium Plant WPM culture medium supplemented with $2 \%$ sucrose, $\mathrm{pH} 5.7$ and solidified with $6 \mathrm{~g} \mathrm{~L}^{-1}$ agar. The plantlets were kept in a growth room at $25 \pm 1^{\circ} \mathrm{C}$, under $16 \mathrm{~h}$ light and $32 \mu \mathrm{Mm}^{-2} \mathrm{~s}^{-1}$ of light intensity. To establish the treatments, plantlets were separated in groups according to the size: 2.5 to $2.4 \mathrm{~cm}$; 5 to $7 \mathrm{~cm}$ and 8 to $10 \mathrm{~cm}$ long. After the separation, the material was irradiated with gamma rays in doses of $10,20,30,40$ or $50 \mathrm{~Gy}$. The apparatus used for the irradiation process was 'Gammacell 220' with 60 Co radioisotope (dose rate of $0.877 \mathrm{kGy} \mathrm{h}^{-1}$ ). In a continuous flow chamber the plantlets were cut into 1-cm explants containing 1 bud. When transferred to new test tubes containing the same nutritive medium the explants were separated according to bud position: basal, medium or apical.

All the material was kept in a growth room, at the same incubation conditions described previously. Plantlets were inspected weekly to identify anomalies and/ or death of explants. Ninety days later, the following characteristics were evaluated: height of aerial part, number of buds per plantlet and fresh weight of the plantlet. Based on the tested factors, the experimental design was completely randomized, in a $6 \times 3 \times 3$ fac- torial scheme for doses, size, and position, respectively, with four replications and three plantlets per plot. The factors were analyzed by polynomial regression using the SISVAR statistical program (Ferreira, 2000).

\section{RESULTS AND DISCUSSION}

The tested doses of gamma irradiation did not cause plantlet mortality. No alteration on the architecture and color of the irradiated plantlets were observed. These results differ from those found for explants of fruit plant species irradiated in vitro, such as 'Gravesac' rootstock grape (Silva \& Doazan, 1998) and Japanese plum (Prunus saliciana Lindl.) cv. Shiro, for which Predieri \& Gatti (2000) observed death of plantlet at 30 Gy irradiation. However, no root formation was observed in plantlets which were irradiated with doses above $30 \mathrm{~Gy}$. The absence of roots is common under certain irradiation doses (Tulmann Neto, 2000), and this fact had already been observed in other fruit plant species such as grape rootstock (Silva \& Doazan 1995) and plum (Predieri \& Gatti, 2000).

There was interaction between irradiation dose and bud size, in relation to height of aerial part, number of buds and fresh weight, which are graphically represented in Figures 1, 2 and 3. Plantlet fresh weight was the more affected variable by irradiation. A decreasing model for all plantlet sizes tested was found, indicating an inverse association between the two parameters. For the other variables, this same trend was found for the sizes 2.5 to $4.5 \mathrm{~cm}$ (T1) and 8 to $10 \mathrm{~cm}$ (T3).

It is possible to observe that 5 to $7 \mathrm{~cm}$ long fig plantlets (T2) were the most affected by the radiation (Figure 3), expressed by the greatest reductions in weight under increasing irradiation doses and the one that yielded the largest size of aerial part $(3.65 \mathrm{~cm})$, recorded under the dose of $6.4 \mathrm{~Gy}$. The greatest num-

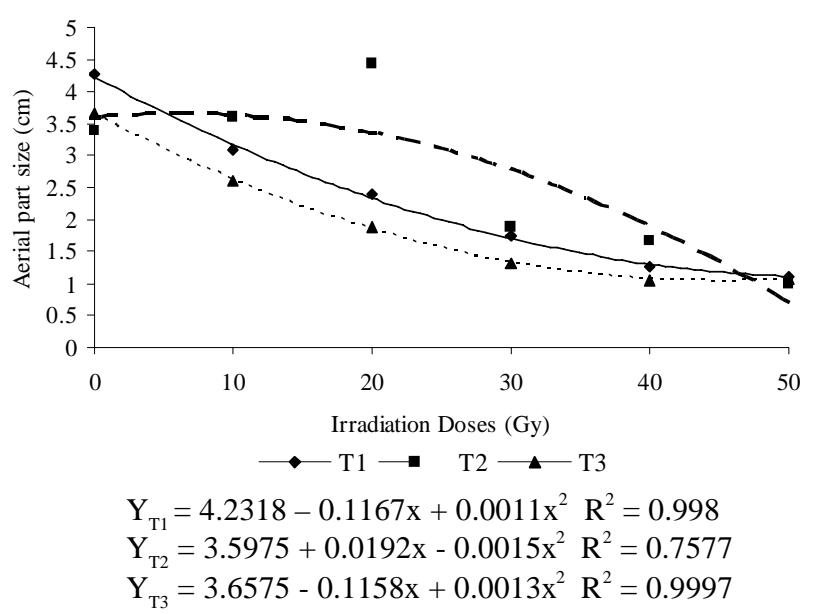

Figure 1 - Average length of fig plantlet aerial part, subjected to increasing irradiation doses. Sizes: T1 2.5 to $4.5 \mathrm{~cm}$; T2 5 to $7 \mathrm{~cm}$; T3 8 to $10 \mathrm{~cm}$. 


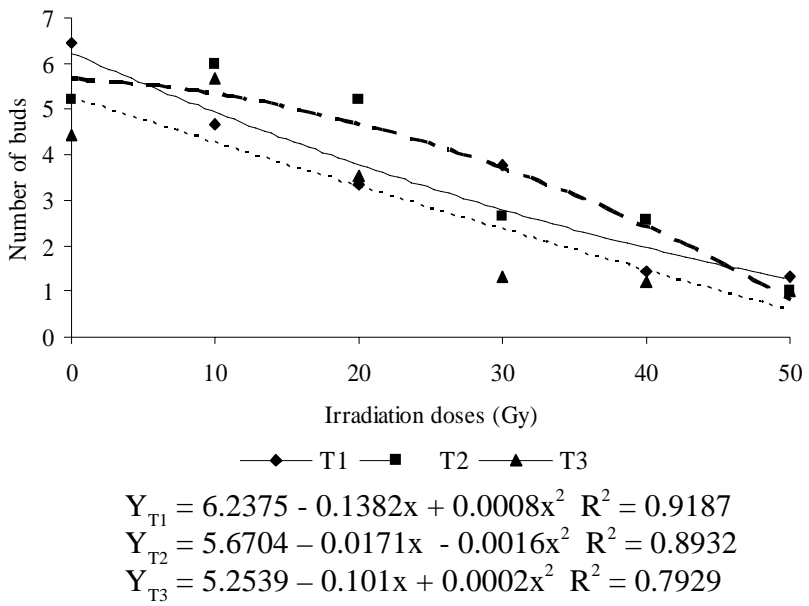

Figure 2 - Average number of buds in fig plantlets subjected to different irradiation doses. Sizes: T1 2.5 to $4.5 \mathrm{~cm}$; T2 5 to $7 \mathrm{~cm}$; T3 8 to $10 \mathrm{~cm}$.

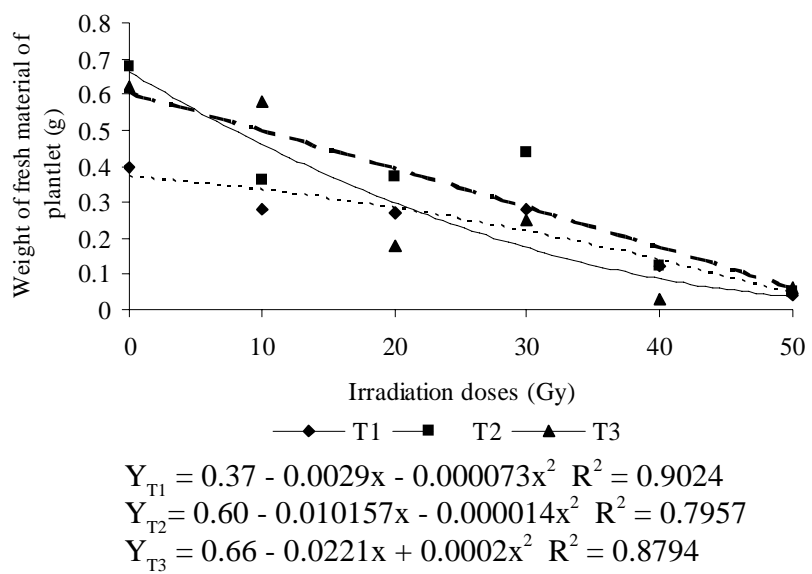

Figure 3 - Fresh weight of fig plantlets subjected different irradiation doses. Sizes: T1 2.5 to $4.5 \mathrm{~cm}$; T2 5 to 7 $\mathrm{cm}$; T3 8 to $10 \mathrm{~cm}$.

ber of buds was found in 2.5 to $4.5 \mathrm{~cm}$ plantlets, under the dose of $8.63 \mathrm{~Gy}$, yielding an average of 5.64 buds. The results are in agreement with those of Bhagwat \& Duncan (1998), who stated that, after irradiation, survival and regeneration capacity vary as a function of the dose and of the vegetal material irradiated.

The $50 \%$ reduction on the recorded values for the analyzed variables occurred starting from the dose of $30 \mathrm{~Gy}$, for both aerial part size and bud number. Under this dose the 8 to $10 \mathrm{~cm}$ irradiated plantlets (after being cut to separate apical, medium and basal buds) presented the same value for size and bud number (1.33), with a reduction of $63 \%$ and $69 \%$, respectively, in comparison with the control (plantlets with $3.66 \mathrm{~cm}$ and 4.44 buds). However, for the 2.5 to 5 $\mathrm{cm}$ and 5 to $7 \mathrm{~cm}$ irradiated plantlets, this reduction was noticed starting from the dose of $40 \mathrm{~Gy}$, for the same variables analyzed.
The dose of 20 Gy caused a 70\% reduction in plantlet fresh weight regardless of the plantlet size during irradiation, with average of $0.27,0.37$ and $0.18 \mathrm{~g}$, for the sizes 2.5 to $5 \mathrm{~cm} ; 5$ to $7 \mathrm{~cm}$ and 8 to $10 \mathrm{~cm}$ (control $0.4 ; 0.68$ and $0.62 \mathrm{~g}$ ), respectively.

The reduction on plantlet development at specific doses of irradiation is considered normal in studies involving mutation. According to Mohan Jain (2006), it is related to the fact that cells which underwent irradiation and suffered some type of physiologic or chromosome damage present lower mitotic capacity, in contrast with cells that did not suffer irradiation, justifying the observations found in the present study.

\section{CONCLUSION}

For the irradiation of fig plantlets "Roxo de Valinhos", larger than $2.5 \mathrm{~cm}$, the dose $30 \mathrm{~Gy}$ is recommended.

\section{REFERENCES}

BHAGWAT, B.; DUNCAN, E.J. Mutation breeding of highate (Musa acuminate, AAA) cubense for tolerance to Fusarion oxiporum f.sp. cubense) using chemical mutagens. Euphytica, v.73, p.143$150,1998$.

CRISTOFANI, M.; MENDES, B.M.J.; TULMANN-NETO, A.; ANDO A. Determinação da viabilidade de protoplastos irradiados de laranja 'Pera'. Bragantia, v.52, p.101-104, 1993.

DOMINGUES, E.T.; TULMANN-NETO, A.; MENDES, B.M.J.; ANDO, A. Efeitos de doses de raios gama em ápices caulinares de bananeira (Musa sp.) desenvolvidos in vitro para indução de mutação. Pesquisa Agropecuária Brasileira, v.29, p.10911098, 1994.

FERREIRA, D.F. Análises estatísticas por meio do Sisvar para Windows versão 4.0. In: Reunião anual da Região Brasileira da Sociedade Internacional de Biometria, 45., São Carlos. Anais. São Carlos: UFSCar, 2000, p.255-258.

MOHAN JAIN, S. Mutation assisted breeding for improving ornamental plants. Acta Horticulturae, n.714, p.85-98, 2006.

NAGATOMI, S.; DEGI, K.; YAMAGUCHI, H.; MORISHITA,T.; YUI, M. Four mutant varieties induced by gamma rays and in vitro culture in chrysanthemum. Japan: Institute of Radiation Breeding, 2003. 2p. (Technical News, 64).

PREDIERI, S.; GATTI, E. Effects of gamma radiation on microcuttigs of plum (Prunus salicina Lindl,) 'Shiro. Advanced Horticulturae Science, v.14, p.7-11, 2000.

SANTOS, P.C.; TULMANN-NETO, A. Sensitividade de estacas de figo a radiação gama. Revista Brasileira de Genética, v.20, p.150-153, 1997.

SILVA, A.L.; DOAZAN, J.P. Une méthode d'irradiation aux rayons gamma aplpliquée a dês porte-greffes de vigne in vitro. Journal International de la Vigne et du Vin, v.29, p.1-9, 1998.

SPIEGEL-ROY, P. Economic and agricultural impact of mutation breeding in fruit trees. Mutation Breeding Review, v.5, p.26, 1990.

TULMAN-NETO, A.; MENDES, B.M.J.; DUTRA VAZ, F.B. (1999) Applications Of In Vitro Mutation Breeding. In: SIDDIQ B.A.; KHAN S... (Ed.) Plant breeding advances \& in vitro culture. New Delhi - Índia: CBS Publishers \& Distributors, 1996, p. 254-268.

TULMAN-NETO, A.; SANTOS, P.C.; LATADO, R.R. (2000) Aspectos sobre o melhoramento da figueira (Ficus carica L.). In: SIMPÓSIO BRASILEIRO SOBRE A CULTURA DA FIGUEIRA, Ilha Solteira, 1999. Anais. Ilha Solteira: UNESP, 259p.

Received August 14, 2007

Accepted February 17, 2009 